\title{
Condomínios Habitacionais Fechados e Qualidade de Vida Uma discussão (também) sobre a Cidade
}

Marta Ferreira Martins*

\begin{abstract}
Resumo: 1) Com a ausência, em Portugal, de um enquadramento legal preciso, a noção de condomínio habitacional fechado remete-nos à consideração de um universo arquitectónica, social e simbolicamente heterogéneo. 2) O fenómeno do seu surgimento e expansão convida-nos a interpelar, de forma indissociável, Espaço, Cidade e Democracia, revestindo-se, tal interpelação, de um particular potencial estratégico na discussão em torno da cidade que temos e sua transformação na cidade que queremos. 3) Os marcadores materiais e simbólicos que operam a distinção dos condomínios habitacionais fechados entre a generalidade dos condomínios, a imaginação sobre quem neles vive e as razões e impactes subjacentes à sua origem e expansão, assumiram-se como temáticas orientadoras da provocação e da descoberta dos discursos de um conjunto de interlocutores social e culturalmente diversos, distintamente associados à produção e apropriação social de alguns destes empreendimentos, localizados na cidade de Lisboa. 4) Um diálogo analiticamente estabelecido entre residentes, agentes associados à oferta de espaço residencial, investigadores e decisores políticos, do qual - por entre linhas de ruptura - emergem interessantes e preocupantes espaços de consenso e compreensão mútuas, nele se aclarando elencos de preocupações e reivindicações produzidas sobre a cidade actualmente existente, os quais se afiguram partilhados entre confessados adeptos e assumidos opositores destes empreendimentos. Endereçado o desafio, como poderá a Cidade responder?
\end{abstract}

Palavras-chave: Condomínio Habitacional Fechado; Espaço; Habitat; Cidade; Qualidade habitacional; Qualidade de vida.

\section{Condomínio habitacional fechado: uma noção fechada?}

De que falamos quando falamos de condomínios fechados?

A acepção a que, neste âmbito, nos atemos, designa um modo de agregação formal das vizinhanças, o qual assume a natureza de produto imobiliário vocacionado para uma função residencial.

Ausente, em Portugal, de um enquadramento legal preciso, a noção de condomínio habitacional fechado (CHF) remete-nos, contudo, à observação de um universo heterogéneo, desde logo na plasticidade morfológica das paisagens publicitadas e reconhecidas enquanto tal. Ante tal heterogeneidade plástica, os descritores que autonomizam uma noção de condomínio fechado reportam, propõe a socióloga Rita Raposo (2002: 59-60), à conju- gação das dimensões de: a) clausura (associada à impermeabilidade física dos perímetros e aos dispositivos e práticas de controlo da acessibilidade e da circulação aos/nos empreendimentos); b) disponibilidade e usufruto de amenidades - equipamentos e/ou serviços - de utilização colectiva; e c) "propriedade privada (...) colectiva de espaços exteriores associados à função residencial (indissociável da propriedade privada e individualizada de fracções ou unidades de habitação autónomas)" "

A inexistência de uma definição consensual e a aplicação internacionalmente generalizada (e equívoca) da expressão gated community - assente na explícita ou tácita adesão a um tipo-ideal de condomínio fechado - legitimam, todavia, tipificações diversas, assentes na multiplicidade de enfoques teóricos e metodológicos que orientam diferentes histórias de pesquisa. Esta preciosa e saudável

\footnotetext{
*Socíloga, Doutoranda em Sociologia no ISCTE-IUL. Contacto: martamartins78@gmail.com

1 A última dimensão permite distinguir entre CHF e outros edifícios habitacionais (uma moradia unifamiliar, por exemplo) que, não incluídos em qualquer particular empreendimento, podem, isoladamente, apresentar características identificadas com as duas primeiras dimensōes, de clausura e usufruto de amenidades.
} 
diversidade comporta, contudo, consequências que importa não desprezar. Eventuais entendimentos e opções conceptual e metodologicamente distintas podem explicar alguns desencontros abruptos. Por exemplo, até 1993, para a geógrafa Maria Júlia Ferreira (2001: 64), seria possível referenciar 21 CHF em Portugal continental. De acordo com um recenseamento levado a cabo por Rita Raposo, até 1993, haveria - só na AML - 44 CHF (Raposo, 2002: 375)...

No que se afigura como desafio eventualmente incontornável, adite-se que falar em condomínio fechado significa aludir a uma situação de facto e não de direito, sendo comuns os casos de empreendimentos que, legalmente inibidos de controlar o acesso e a circulação de indivíduos e veículos, tornam de facto, pela clausura e interiorização de espaços de domínio público, "menos provável a entrada de estranhos" (Idem, ibidem, 2002: 57-58; Low, 2003: 12). Importando referir que a manutenção destas áreas interiorizadas, é geralmente, parcial ou totalmente, assegurada por entidades públicas.

Imagem 1 - Uma portaria e uma cancela resguardam a principal entrada para o espaço interior, juridicamente público, da Quinta da Beloura, em Sintra, a 30 quilómetros de Lisboa.

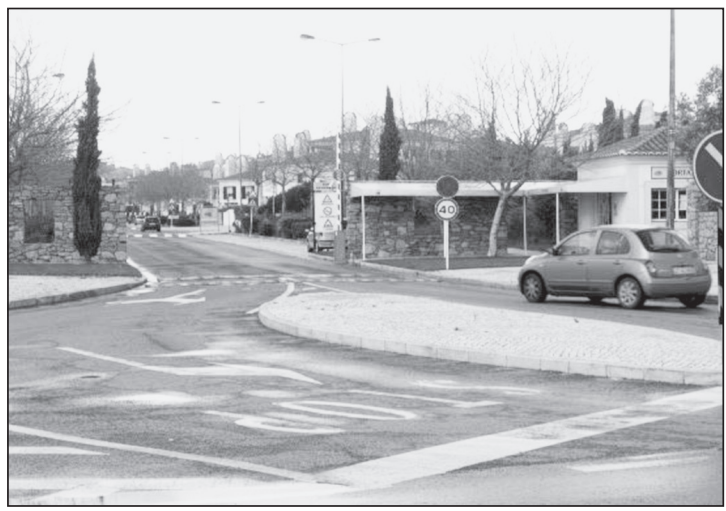

Foto da autora

\section{Impressões e perplexidades}

O confronto com a simultânea condição física, social e simbólica do espaço constitui um problemático e afamado desafio.

Recusado enquanto natureza exclusivamente material e aleatória - bioquímica na sua constituição, transformação e mudança, impondo-se apenas como constrangimento a uma forçada e reactiva ho- meostasia da espécie - o espaço consubstancia, sim, um terreno significante de interacção. Cenário construído, manipulado, de inscrição activa e criativa do Homem num real fisicamente percepcionado, social e culturalmente percebido, o espaço existe também como palco e como recurso, consubstanciando um sistema de coordenadas mentais de orientação e representação no/do mundo.

$\mathrm{O}$ discurso quotidiano apresenta-se como tradução simultânea do espaço socialmente incorporado, reconhecido ejulgado pelos indivíduos. De alguma forma, se "cada um sabe [ou imagina] a que se refere quando fala", por exemplo do largo da praça, do mercado, do centro comercial, de um lugar público, etc." (Henry Lefebvre, citado por Guerra, 1987: 113), é porque as referências discursivas identificam convenções de usos socialmente associados ao(s) espaço(s), nelas se revelando conotações e valorações normativas, socialmente produzidas sobre o(s) mesmo(s).

Os anteriores pontos são particularmente importantes para nos recordar que, na distância entre objecto empírico e objecto conceptualmente construído, as viagens dos significados e dos sentidos reservam serendipidades múltiplas... E neste sentido vale a pena reter que, além de qualquer afunilamento conceptual, condomínio fechado é também uma ideia que viaja no senso comum, sendo comummente resgatada para explicitar sentidos e coisas outras, não necessariamente reportadas sequer a formas habitacionais...

Imagem 2 - Condomínios Fechados. Título da fotografia de Muñoz de Oliveira, que acrescenta: "estes sim merecem sê-lo, para sua protecção"

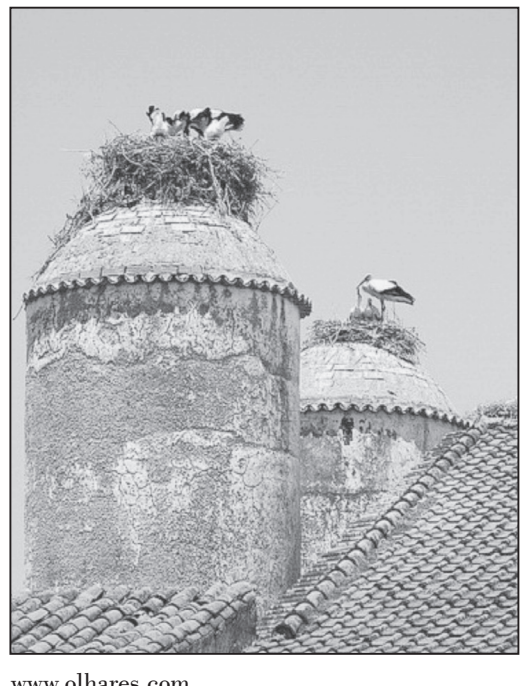

www.olhares.com 
De que falamos, pois, quando falamos de condomínios fechados? Devemos bloquear em face de um problema de identificação do objecto?

Consideremos a resposta recorrentemente encontrada no decurso do trabalho de campo, a uma pergunta simples: conhece algum condomínio fechado em Alcântara?

Ainda que de forma não sistemática, repetimo-la algumas vezes, nas ruas de Alcântara² e em conversas informais com amigos e conhecidos, em contextos daí distantes. Construído no espaço de uma antiga fábrica, o empreendimento Alcântara Rio, embora nem sempre nomeado, assumia-se ordinariamente como a primeira sugestão de resposta.

Trata-se de uma resposta curiosa, porquanto aquele empreendimento não partilha dos elementos usualmente propostos como descritores de o que é um condomínio fechado: nele não se verifica uma impermeabilidade física de acesso ao espaço, não dispõe de recursos humanos e tecnológicos não convencionais aplicados a uma eventual vigilância sobre as áreas ajardinadas que preenchem o espaço entre os vários blocos habitacionais - e encontra-se ausente de amenidades partilhadas.

Originalmente publicitado como o primeiro empreendimento loft em Lisboa, este projecto imobiliário é, ao invés, bem conhecido por concentrar, na base dos edifícios que o compõem, alguns novos, trendy e exóticos bares e restaurantes, de acesso não restrito... Justificando a resposta, vários elementos ressoavam como conteúdos de outras possíveis definições sobre o que é um CF: "por ter jardins", "porque é bem cuidado, limpo...", "por não se verem papéis no chão...", "por aquilo ser meio fechado, $e$ ter uma parte atrás...", "por não saber como se entra lá...", "porque a arquitectura é completamente diferente do resto", "por ser novo e ter uma grande área"...

Além de qualquer delimitação teórica de um objecto, a consideração sobre se determinada paisagem é ou não é um CHF, afigura-se também como um juízo social e culturalmente mediado.
Imagens 3 e 4 - Empreendimento Alcântara Rio, construído nas instalações de uma antiga fábrica em Alcântara, Lisboa.
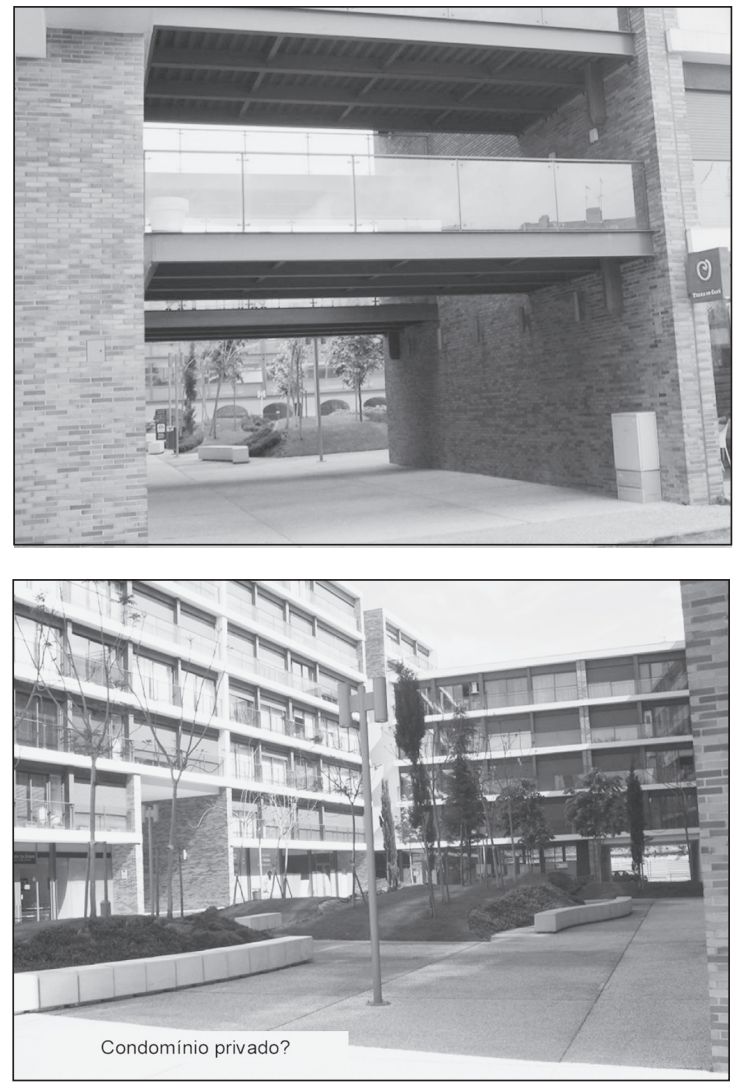

Fotos da autora. Para mais informações sobre o projecto, poderá consultar-se: http://www.invistacasa.com/alcantara/index.html)

\section{Objecto e vocação da pesquisa}

Iluminando com peculiar acutilância a complexidade do entendimento sobre o Espaço, a atenção votada à experiência atrás relatada definiria a vocação de uma pesquisa cujo primordial questionamento convidava à descoberta de alguns dos conteúdos associados à ideia de condomínio habitacional fechado, por actores social e culturalmente diversos - distintamente associados ao processo de produção e apropriação social de empreendimentos assim classificáveis, localizados na cidade de Lisboa.

Tendo por base o anterior questionamento de partida, a pesquisa desenvolver-se-ia sob a imanência da seguinte preocupação: podemos captar,

\footnotetext{
${ }^{2}$ Espraiando-se até junto ao rio Tejo Alcântara é um dos bairros antigos, populares, de Lisboa, tendo sido outrora um ponto de particular concentração de unidades industriais e actividade portuária.
} 
pela colecção e análise das representações associadas à ideia de condomínio habitacional fechado, um conjunto de reivindicações em relação à cidade partilhadas de forma socialmente mais extensa, não sendo específicas dos indivíduos que autonomamente optam por residir em empreendimentos considerados como tal (e que não necessariamente gostariam de lá viver)?

Dando corpo à dissertação de licenciatura em Sociologia pelo ISCTE, no âmbito da qual se realizou um estágio no Núcleo de Ecologia Social do Laboratório Nacional de Engenharia Civil (NESOLNEC), o trabalho de campo da pesquisa decorreu entre 2005 e 2006.

Desdobramento do questionamento inicial, os marcadores materiais e simbólicos que operam a distinção dos CHF entre a generalidade dos condomínios, a imaginação sobre quem neles vive, as razões e impactes subjacentes à sua origem e expansão, assumir-se-iam como temáticas orientadoras da provocação e descoberta dos conteúdos associados à ideia de CF, bem como ao fenómeno do surgimento e expansão dos empreendimentos residenciais (re)conhecidos como tal. Perseguindo-se a complementaridade e não a comparabilidade dos dados (Freitas, 2001: 162), o diálogo analítico estabelecer-se-ia entre ${ }^{3}$ :

- Agentes directamente associados ao uso/ /apropriação presencial em CHF (oito residentes em três CHF situados nos bairros de Benfica, Graça e Alcântara);

- Actores associados à oferta de espaço residencial (um promotor, um mediador imobiliário, um arquitecto projectista de um CHF, um profissional especializado na administração destes empreendimentos);

- Interlocutores considerados privilegiados numa abordagem às questões do Alojamento, não directamente associados ao fenómeno em causa (4 arquitectos, particularmente dedicados à investigação sobre o desenvolvimento da qualidade habitacional);
- Actores associados à regulamentação/gestão/ /decisão autárquica (uma gestora de topo e um técnico intervenientes, na Câmara Municipal de Lisboa, na intervenção/planeamento territorial).

\section{Aberto, fechado... dicotomias ou continuidades?}

Os conteúdos associados ao surgimento e à expansão dos CHF guardam um particular potencial estratégico na discussão sobre a Cidade.

A pertinência desta asserção assenta na contemplação do espaço enquanto continuum em apreciação, concepção explorada pela investigação produzida sobre a formulação da satisfação residencial. Convidando à descentralização de um olhar direccionado sobre a casa, esta última constrói-se num "constante vai e vem entre as diferentes dimensões espaciais do habitat", as quais desenham uma espiral integrando "desde os espaços e compartimentos no interior dos alojamentos às suas áreas envolventes", aos espaços "de uso semi-público como os edifícios, [e aos] de uso mais colectivo, como as vizinhanças próximas" (Freitas, 2001: 269).

Imagem 5 - Espiral de níveis físicos residenciais (Freitas, 2001: 37), Ou "o jogo da glória diário" desenhado pelos percursos imaginados e concretizados pelos indivíduos no espaço construído (Coelho \& Pedro: 2).

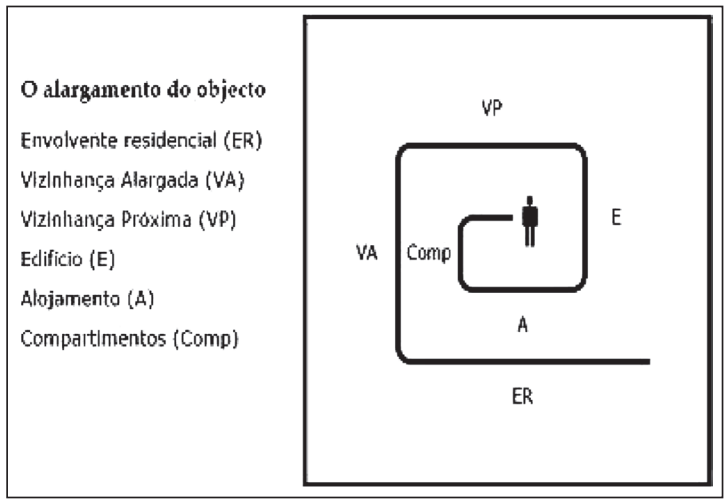

\footnotetext{
3 A entrevista semi-directiva foi a técnica de recolha de dados privilegiada, complementada com episódios informais de observação directa nos CHF e suas vizinhanças próximas. Dispondo de áreas/amenidades comuns (jardins, piscina, existentes em todos), os empreendimentos são clausurados, por efeito de barreiras arquitectónicas (gradeamento, no caso da Graça; gradeamento e próprio edificado nos outros casos), existência de portarias e meios humanos de vigilância 24 horas por dia. Por relação pessoal directa (no caso dos residentes) ou profissional (casos do promotor imobiliário, arquitecto projectista, mediador imobiliário, e gestor da empresa de administração de condomínios), os empreendimentos congregavam alguns dos interlocutores.
} 
Num segundo passo interpretativo, importa sublinhar que os factores eficientes do bem-estar residencial não apenas reportam aos distintos níveis residenciais (Coelho, 1998: 140), como não se reduzem, única e primordialmente, às características materialmente edificadas desse contexto. Mais do que um valor de uso e "valor intrínseco dos objectos", o valor simbólico do alojamento confere ao espaço "uma função [e um poder] social de espelho do que são, ou se aspira a que seja, [em determinados] quadros colectivos de acção, os posicionamentos relativos aspiráveis ou expectáveis dos seus actores" (Freitas, 2001: 262). Assim,

" (...) as necessidades habitacionais e residenciais e a manifestação da sua satisfação por parte dos indivíduos adquirem um estatuto relacional entre os indivíduos e a sociedade, que não se configura ao alojamento ou ao conforto do lar; estas estendem-se à cidade enquanto cenário de relação colectiva onde as coisas e os indivíduos ganham e constroem os seus valores no posicionamento relativo que ocupam e conquistam" (Idem, ibidem: 270).

Importa, contudo, notar que a apreciação do espaço enquanto todo de continuidades não se processa de forma linear. Ao contrário, tal apreciação é intrinsecamente estruturada por dinâmicas relacionais de construção, comunicação e tradução simbólica de descontinuidades e dissemelhanças entre pólos: entre o percepcionado perto ou longe, fora ou dentro, lá em cima ou cá em baixo, nosso ou deles, entre o julgadofeio/belo, confortável/desconfortável, entre o que se separa como partes onde vamos e não vamos (Menezes, 2004: 120).

Instrumentos inerentes à organização do tempo, espaço e experiência social e sensorial dos indivíduos (manifestando esse ordenamento), em tais processos reconhecemos as noções de limite e de fronteira - entendidas não como sinalizações materialmente edificadas de inevitável ruptura, mas como processos de negociação tensa dos significados simbólicos dos lugares, bem como da codificação e (re)conhecimento dos rituais (de uso e pensamento) considerados adequados (Leach, 1978: 44-46) no confronto e passagem entre pólos distintos. Mais particularmente, é no jogo entre a influência sobre tal ambiguidade e o acatamento de tais preceitos, que reside a manifestação e (re) construção do Poder ${ }^{4}$.

À luz das anteriores considerações, a designação fechada de certos condomínios habitacionais afigura-se particularmente enigmática, importando reflectir sobre o que se entende próprio de cada pólo: o que permanece dentro e fora do condomínio.

Imagens 6 e 7 - O Espaço, um continuum em apreciação... Considerar o Espaço como um continuum em apreciação convida-nos a questionar usuais dicotomias e mútuas exclusões analíticas. Compreender a natureza social construída de categorias como público e privado - também a partir da diferenciação entre âmbitos jurídico, de uso e apropriação (Castro, 2002: 54) - prepara-nos desafia-nos a receber paisagens aparentemente estranhas. Em baixo, a entrada para o Páteo Bagatella, um empreendimento de alto standing no coração de Lisboa, nas Amoreiras - cujos portões permanecem abertos e publicamente acessíveis durante o dia. Na passagem interior, que liga duas ruas públicas paralelas, alguns cafés e lojas podem ser visitados durante o dia. Na página seguinte à direita, a entrada para o Jardim da Estrela, um dos maiores parques lisboetas, situado no bairro da Estrela - cujos portões são fechados todas as noites, naturalmente respeitando um horário previamente estabelecido de visita...

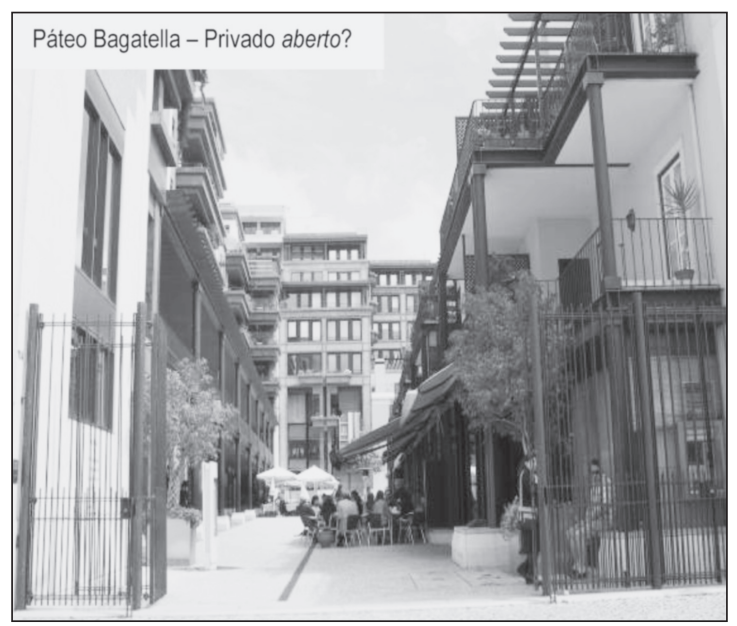

\footnotetext{
4 Referencie-se, a este propósito, a reflexão da antropóloga Antónia Lima, sobre como as regras e os rituais de estabelecimento de contactos entre investigador e investigados dificultam "o exercício da etnografia sobre as elites" (1997: 111-112).
} 


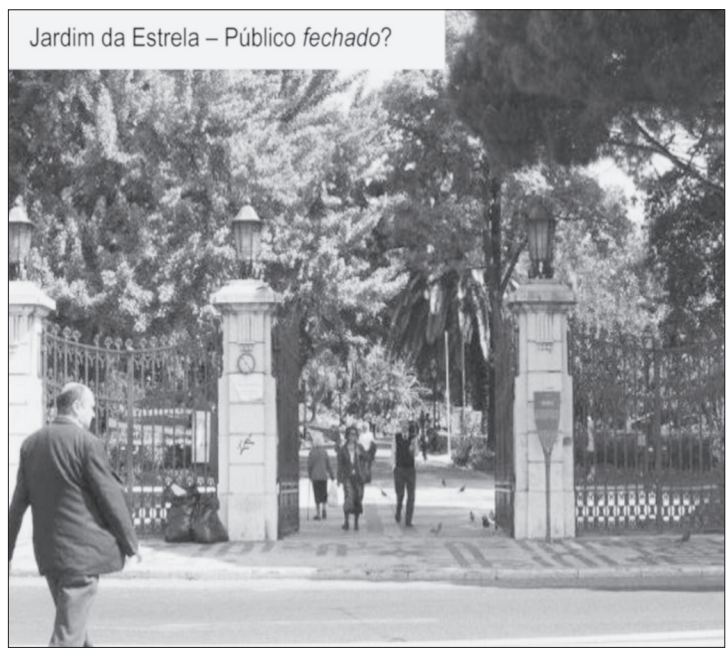

Fotos da autora

Imagens 8 e 9 - A não linearidade de um continuum... Enquanto "gradação de intimidades" (Coelho \& Pedro, 1998: 300), a formulação arquitectónica da privacidade não implica necessariamente um só modelo de comunicabilidade entre dois espaços. Nomeadamente, não obriga à adopção de um modelo que obste à autónoma acessibilidade e promova a opacidade visual entre ambientes que se pretendem distintos. Não impedindo a acessibilidade, a pérgula (à esquerda), transmite a sensação de transição para um interior, reservado. Exterior e interior, assim percepcionados, são espaços de acesso livre, não formalmente controlado. Ante a frontaria do CHF Residências do Príncipe Real (Lisboa) (à direita), assiste-se a algo mais do que a formulação do sentimento de privacidade; assiste-se à exibição de um direito de propriedade, manifesto pela demarcação imediatamente física de uma área, à qual se acede sob determinadas condições.

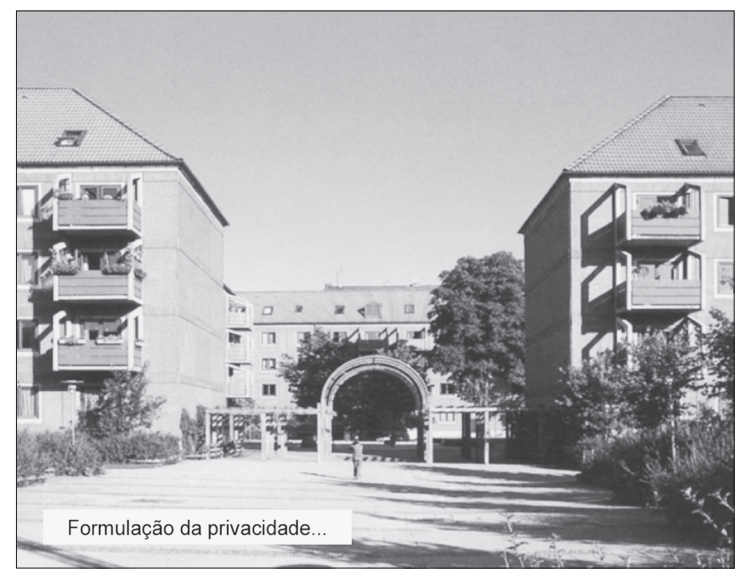

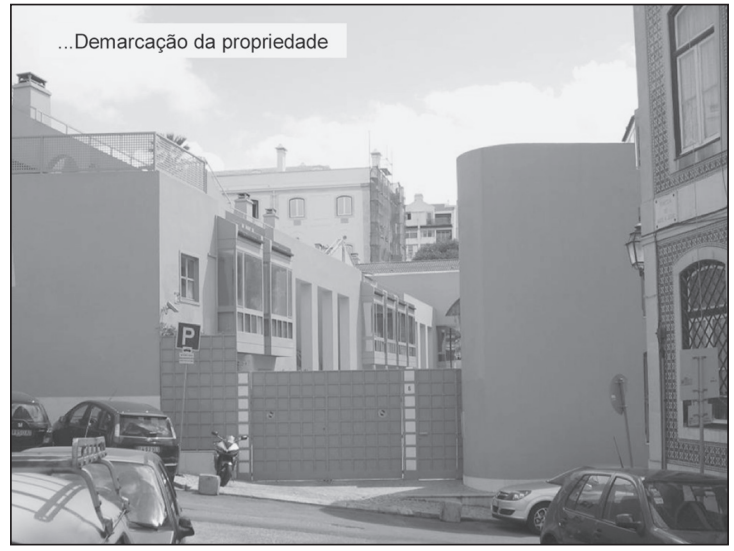

Um fenómeno pouco consensual

$\mathrm{O}$ surgimento e a expansão dos $\mathrm{CHF}$ parece corresponder à reedição de um fenómeno cujos antecedentes reportam às praças residenciais britânicas (privatizadas por colectivos de residentes) e, pouco mais tarde, ao subúrbio romântico planeado anglo-americano (Raposo, 2002: 159-219). Formas emergentes entre meados do século XVIII e finais do século XIX, estas são formas indissociáveis de um tempo de transformações que ditariam o derrube jurídico e institucional do Antigo Regime - um tempo em que a renovação de barreiras à acessibilidade/comunicabilidade surge, no que aos modos de habitar concerne, como modo de reequilibrar posições e estatutos entre novos e velhos grupos sociais, relacionados segundo uma nova lógica económica e cultural, capitalista (Idem, ibidem).

Surgido na Califórnia (EUA) em finais da década de 60 do século xx, o actual momento comporta importantes inovações, manifestando-se em diversos contextos socioespaciais e concretizando-se em maior número (Nunes em Ferreira et al., 2001: 31; Raposo, 2002: 225; Low, 2003: 16).

Progressivamente manifestando-se "num âmbito cívico mais alargado" (Blakely \& Snyder, 1997: VIII), o surgimento e a expansão dos CHF vem alcançando uma visibilidade pública marcadamente pouco consensual, visitada por concepções que, sobre tal fenómeno projectam um conjunto de perigos e potencialidades.

Imagem 10 - Questionando pela Arte. Plataformas de Observação instaladas pelo colectivo artístico Heavy Trash, movimento anónimo de arquitectos, designers e urban planners, na entrada 
de dois dos CHF de Los Angeles (EUA) - Brentwood Circle (à esquerda) e Laughlin Park (à direita) - em Abril de 2005. A intenção subjacente à intervenção: chamar à atenção para a necessidade de pensar sobre o desenvolvimento deste fenómeno. A provocação presente na inspiração: "like the historic viewing platforms at the Berlin Wall that allowed Westerners to see into East Berlin, the Heavy Trash viewing platforms call attention to the walls of gated communities and provide visual access to parts of the city that have been cut off from the public domain"...

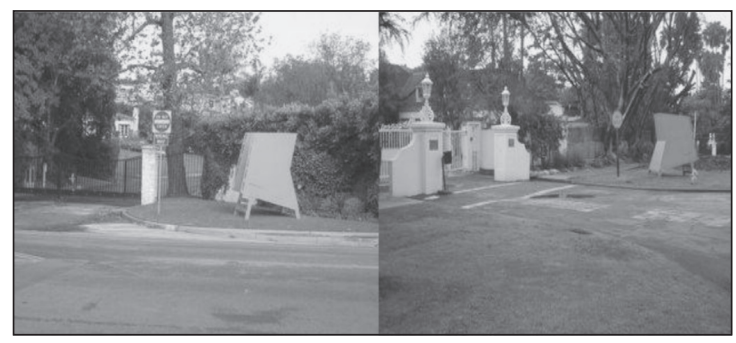

(Consultado em: heavytrash.blogspot.com.)

Publicamente referenciado de forma dispersa, além dos conteúdos de marketing e da crescente produção académica, a construção da visibilidade mais alargada do fenómeno resulta, em Portugal, da episódica discussão sobre a construção de empreendimentos concretos. A defesa do património, entendido como valor histórico e ambiental de determinado contexto local, assume-se como mote privilegiado obscurecendo, nas contendas, a questão segregativa ${ }^{5}$.

Esta insinuar-se-ia mais claramente aquando da campanha para as eleições autárquicas de 2005, em Lisboa. Apontados como exemplos paradigmáticos de segregação socioespacial, os CHF seriam não raras vezes apresentados como pólos socialmente opostos aos designados bairros sociais.

Talvez possa contestar-se tal paralelo, olhando quer às géneses de uns e outros espaços, quer à subjacente consideração de que se tratam de pólos extremos da desigualdade social. Desconfortavelmente reconhecendo a imoralidade e pouco rigor na comparação entre misérias, dir-se-á que os mais ricos não vivem necessariamente em $\mathrm{CF}$, assim como os mais pobres, não vivem nos bairros sociais...

Meios de reinvenção e policiamento social da distinção entre grupos aproximados pela extensividade das crises económicas e pelo aprofundamento dos processos democráticos (Caldeira, 2000)... Habitação sem cidade ou ninhos numa uma cidade ameaçada? Redutos de todos os individualismos $\mathrm{e}$ demissão, ou laboratórios de governança e racionalidade económica (Foldvary, 2006: 31)?

O quadro 1 resume alguns dos principais eixos de debate.

Quadro 1 - Alguns eixos de debate em torno da expansão dos CHF

\begin{tabular}{|l|l|}
\hline \multicolumn{1}{|c|}{ Uma visão pessimista! } & \multicolumn{1}{|c|}{ Uma visão optimista! } \\
\hline Demissão/Renúncia de cidadania & Exercício de direito de cidadania (optar por um CF) \\
\hline $\begin{array}{l}\text { Ameaça ao monopólio público da violência (ideologia } \\
\text { preventiva aplicada a comportamentos de auto-defesa) }\end{array}$ & Protecção contra a experiência de vitimação pelo crime \\
\hline $\begin{array}{l}\text { Demarcação ostensiva de desigualdades sociais (ameaça } \\
\text { ao sentido de coesão social) }\end{array}$ & $\begin{array}{l}\text { Reforço do sentido de vizinhança, humanização das rela- } \\
\text { ções, a redescoberta do outro }\end{array}$ \\
\hline $\begin{array}{l}\text { Desvalorização da heterogeneidade social, (potenciar in- } \\
\text { compreensão da diversidade do outro) }\end{array}$ & $\begin{array}{l}\text { Instrumento de governança (promoção de modos de gestão } \\
\text { comum de espaços mais exigentes em termos de harmoni- } \\
\text { zação de interesses e gostos) }\end{array}$ \\
\hline Deslegitimação do papel/acção/poder do Estado & $\begin{array}{l}\text { Alívio das despesas do Estado (envolvimento/responsabi- } \\
\text { lização dos privados) }\end{array}$ \\
\hline $\begin{array}{l}\text { Obstáculo ao incremento de visão de conjunto na gestão } \\
\text { de recursos e ordenamento territorial }\end{array}$ & $\begin{array}{l}\text { Contribuição para ordenamento global (protecção am- } \\
\text { biental de recursos estratégicos) }\end{array}$ \\
\hline Fuga voluntária à cidade & Retorno feliz à cidade, escape ao stress urbano \\
\hline
\end{tabular}

\footnotetext{
5 Nos anos mais recentes, os casos mais mediáticos terão sido os movimentos de cidadãos contestando a construção dos empreendimentos Convento dos Inglesinhos no Colégio (ou Convento) dos Inglesinhos (Bairro Alto) e Terraços de Bragança, na antiga sede da PIDE-DGS (antigo serviço de informação e censura, durante o regime fascista). Além do problema do património, o acesso aos residentes alcançou também particular relevância nomeadamente na aplicação dos Censos (GOMES, 2001).
} 


\section{Alguns resultados. Algumas ideias}

Não aprofundando aqui as especificidades e fracturas que os estruturam, segue-se a apresentação de alguns fragmentos, genéricos, provenientes da análise dos discursos recolhidos no âmbito da pesquisa.

1. Apontada como principal razão para a procura de CHF nos contextos considerados de origem do fenómeno (EUA e o designado Terceiro Mundo, no qual o Brasil, destacado, surge incluído), o desejo de protecção face à criminalidade não será, para os entrevistados, a razão fundamentalmente subjacente ao surgimento e à expansão destes empreendimentos em Lisboa, cidade aliás referenciada como (ainda) segura no que respeita a tal problema social.

Desvalorizada pelos residentes entrevistados em CHF, tal opção assumir-se-ia aliás, geralmente, nos seus percursos de vida, como uma boa oportunidade, surgida algures no tempo. Na generalidade dos casos - e à semelhança do resultado encontrado noutras pesquisas anteriormente realizadas (DURO et al., 2001; MARTINS et al., 2002; RAPOSO et $a l ., 2007)$ - à decisão de mudança e à subsequente procura de casa, não presidiu a intenção deliberada de se residir num CHF.

2. Ao desenvolvimento do fenómeno em Lisboa preside, segundo os entrevistados, uma multiplicidade de razões, associadas não apenas às lógicas da procura, mas também às estratégias do mercado da oferta de espaço residencial, e à dinâmica de mútuo ajustamento e regulação dos dois mercados, vector em que o Estado e políticas territoriais é particularmente chamado à discussão.
3. Embora sejam diversos os posicionamentos ideológicos de princípio entre confessos adeptos e assumidos opositores dos CHF (residentes e/ou não), detecta-se, por entre profundas discordâncias, interessantes compreensões mútuas. Um importante (e preocupante) espaço de consenso refere-se ao factor considerado mais eficiente para perceber a decisão de residir, em Lisboa, nestes empreendimentos: a fuga à falta de qualidade urbana da $c i$ dade actualmente existente, ancorada no descrédito e desilusão votados ao desempenho dos poderes públicos na gestão e manutenção da coisa pública (e do espaço público). É sobretudo por esta via que assumidos detractores confessam entender as motivações daqueles que escolhem morar em CHF.

Recuando à infância, referem os interlocutores que antes havia vida nas ruas, o que decorreria de um efectivo exercício de planeamento urbano, afiançam, plasmado na existência de sítios para sair à rua: cafés, esplanadas, piscinas públicas... O maior espessamento das relações de vizinhança, o brincar na rua são memórias sublinhadas, num apontamento que replica resultados encontrados, por exemplo, na pesquisa realizada por Setha Low junto de residentes em CHF, em 2003 (2003).

Crescimento desordenado, fealdade, défice de manutenção do espaço urbano são marcas da cidade presente. Escasseiam equipamentos colectivos e, mercê da degradação do edificado e alheamento dos poderes públicos, os CHF configuram excelentes oportunidades de negócio para o mercado da oferta: investindo em espaços de custos inferiores (não raras vezes, degradados), constroem empreendimentos que contrastam com tal paisagem, rentabilizando investimentos. 
Quadro 2 - A cidade actualmente existente, segundo os entrevistados

\begin{tabular}{|l|l|}
\hline \multicolumn{1}{|c|}{ Factores de atracção } & \multicolumn{1}{c|}{ Factores de repulsa } \\
\hline $\begin{array}{l}\text { Proximidade a mais e melhores serviços e equipamentos } \\
\text { colectivos (escolas, transportes, hospitais); }\end{array}$ & $\begin{array}{l}\text { Ausência de planeamento urbanístico e excessiva densi- } \\
\text { dade de construção; }\end{array}$ \\
Mais oportunidades de emprego; & Fealdade do espaço urbano; \\
Maior número de opções/ ofertas de lazer/ actividades & Escassez de espaços verdes; \\
culturais (cinemas, teatros...); & Insuficiente e deficiente manutenção do espaço público; \\
Baixos níveis de criminalidade; & Falta de equipamentos colectivos e de sítios para sair à \\
Simpatia de certas qualidades físico-naturais (a lumino- & rua (falta de animação nas ruas; a rua como um sítio triste \\
sidade, o clima); & para passear...); \\
Reminiscências/hábitos tradicionais, nos bairros antigos.. & Cidade desabitada/degradada (deterioração física do edi- \\
& ficado, edifícios abandonados, desertificação); \\
& $\begin{array}{l}\text { Descaracterização da cidade (destradicionalização do co- } \\
\text { mércio, multiplicação de centros comerciais); }\end{array}$ \\
& Falta de opções no mercado habitacional (casas caras, \\
& escalas desajustadas, demasiado grandes... demasiado \\
& pequenas); \\
& Trânsito (perigo de atropelamento, stress); \\
& Barulho, ruído (particularmente, o associado aos trans- \\
& portes públicos e modo de recolha do lixo); \\
& Falta de estacionamento; \\
& Poluição; \\
& Stress; \\
& Maior incidência e exposição ao crime \\
& Desagregação das relações sociais de vizinhança; \\
& Ter de brincar em sítios fechados (não brincar na rua). \\
\hline
\end{tabular}

4. Os contrastes articulam-se, quer em torno do passado e do presente, quer em torno das designadas cidade-histórica e cidade-dormitório. No balanço, nofascínio da cidade (Ferreira, 2004: 11), sobressai todavia o elogio, não apenas da centralidade da cidade, mas do centro da cidade onde, nos designados bairros antigos, ainda se imagina possível observar ritmos de vida/comércio que, considerados tradicionais, lembram a cidade de antes. Um processo paradigmático da destradicionalização (e, segundo os entrevistados, consequente desqualificação do tecido urbano), refere-se à expansão dos centros comerciais, os quais rompem lógicas consideradas tradicionais do consumo de proximidade. Os bairros limítrofes constituem-se como mais fidedigno espelho da desordem urbana, neles se concentrando, consideram os entrevistados, fenómenos de criminalidade/vandalismo, albergando uma população que, embora profissionalmente pendular, reside física e afectivamente longe da cidade.
5. Os CHF surgem frequentemente referenciados como poderosos sinais de atitudes de fuga em relação à cidade ${ }^{6}$.

Segundo se depreende também doutras análises sobre percursos de residentes em CHF (MARTINS et al., 2002), o sentido de fuga significa sobretudo a conquista de uma distância qualitativa em relação à envolvente. Esta é uma distância que não se mede em quilómetros (apenas) e que em nada se confunde, apesar da crítica à cidade actualmente existente, com o não gostar de viver ou estar em/ /na cidade.

Por conveniência pessoal e/ou profissional, mas também por gosto, importa notar, que, no caso dos residentes entrevistados, à opção de mudar da casa anterior presidiu a necessidade e, nalguns casos, a vontade de viver em Lisboa... Os CHF oferecem-se, aos olhos dos residentes, como oportunidades de regressar e/ou melhor permanecer na cidade

${ }^{6}$ Uma moradia no campo seria, alcança, na generalidade dos entrevistados, o estatuto de casa ideal. Além da proximidade a elementos como $o$ silêncio ou a natureza, sublinha-se a autonomia que a moradia possibilita se fisicamente desligada de outros fogos (permitindo menor dependência de outros na gestão sobre o espaço). 
(e a certas áreas da cidade, como no caso dos bairros antigos $)^{7}$. Sair à noite de casa (descer e fumar um cigarro no jardim...), brincar fora de casa, jantar na varanda, à luz das velas, passear e usufruir de um jardim são experiências tidas, no presente, como excepcionalmente possíveis num CHF.

Imagens 11 e 12 - Da dimensão qualitativa da distância... e sua invenção. Primeira figura em baixo, prospecto publicitário referente à Quinta das Mil Flores, CHF situado em Lisboa, em Sete-Rios. A legenda, fotografia do mesmo empreendimento, rodeado de edifícios e implantado numa área de intenso tráfego.

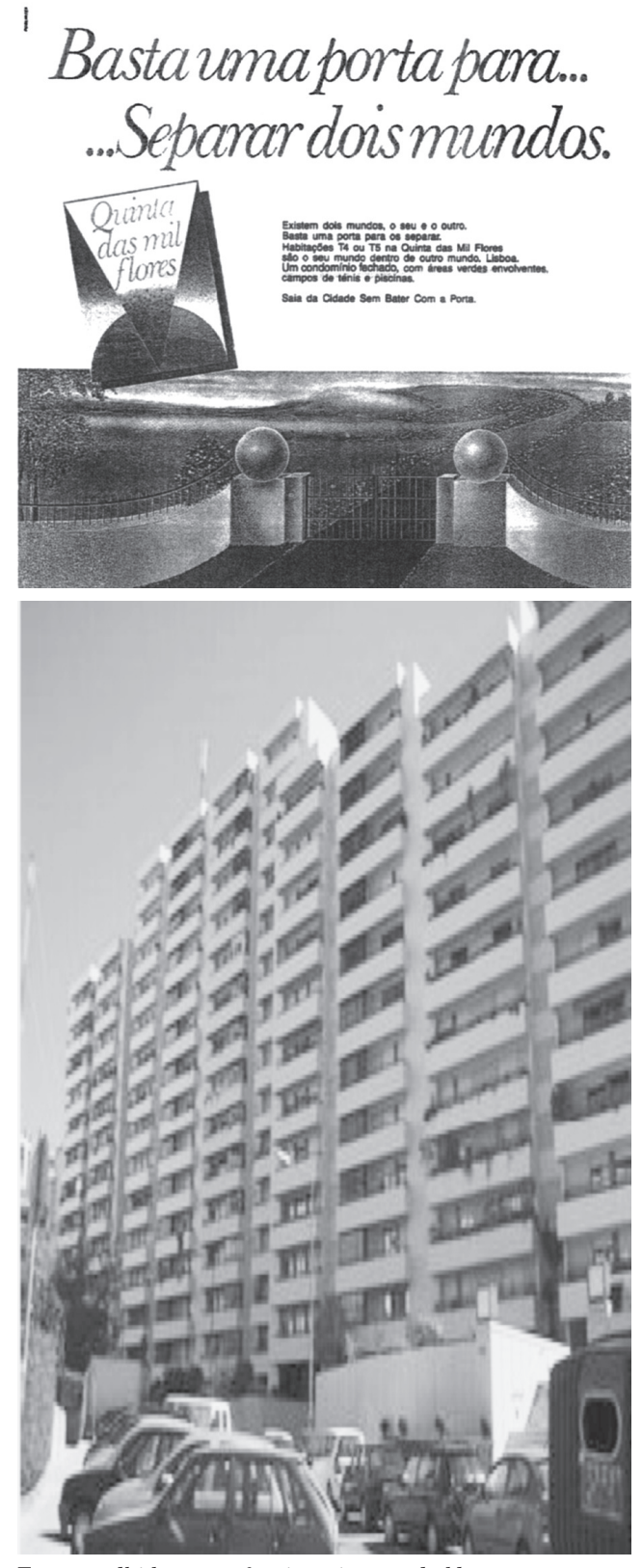

Fotos recolhidas em: ofuncionariocansado.blogspot.com
6. A Qualidade de Vida é um tema frequente e transversal na definição dos elementos que diferenciam os CHF da habitação dita convencional.

Balizada por definições "do que civilizacional, cultural e politicamente se tem vindo a entender por bem-estar, definido quer ao nível individual, quer social ou colectivo" (Freitas, 2001: 114), a emergência do tema desenvolve-se face à progressiva notoriedade dos efeitos perversos de um modelo económico confrontado com “desequilíbrios económicos, a contaminação ambiental, a deterioração das condições de vida e as assimetrias de crescimento entre povos" (Pinto, 2004: 99). Na expressão de Anthony Giddens (1998:5), o lado sombrio da modernidade confunde crescimento económico e desenvolvimento, conjugando "o crescimento urbano massivo e desordenado, a consciência pública sobre [tais] efeitos e a preocupação (...) [das] políticas públicas para melhorar a qualidade de vida nas cidades" (Pinto, 2004: 99, 103, 118).

Contexto de estruturação de novos quadros culturais (Inglehart, 1997), a "consolidação do Estado-Providência, melhoria dos níveis de vida e de formação dos indivíduos" (Pinto, 2004: 99, 103) e o aprofundamento democrático, contribui para que "a discussão do bem-estar social [deixe] de ser uma mera questão de satisfação de necessidades básicas decorrentes dos poderes de compra" (Freitas, 2001: 453).

Recuperando o aforismo segundo o qual as pessoas não são coisas que se metam em gavetas (Guerra, 1994), sublinha-se a ideia enunciada por um dos residentes entrevistados, que, aparente simples, retemos como expressão maior do que vimos referindo: actualmente, "as pessoas já não se contentam apenas com o betão". Exigem coisas outras e novas. Coisas que a subida dos níveis de vida em articulação com o aprofundamento dos sistemas democráticos deslocam da esfera das aspirações para a dimensão presente das necessidades e dos direitos. Usufruir de um jardim, de espaços devidamente tratados, de tempo(s) e equipamentos colectivos vocacionados para o lazer - elementos outrora eventualmente mais excêntricos (uma pis-

\footnotetext{
7 Importará aprofundar a investigação acerca dos modos de gestão da distância qualitativa que, nos CHF, considera conquistar-se em relação à envolvente próxima, reflectindo sobre a menor ou maior distanciamento físico relativamente a referências mentais que podem, obviamente, não passar nem por Lisboa, nem por cidades (Martins et al., 2002).
} 
cina, por exemplo)... coisas que, os CHF, julgam os entrevistados, tornam possível.

Imagem 13 - Anúncio ao Belas Clube de Campocentro natural de descompressão - empreendimento de larga escala, situado em Belas, subúrbio verde da AML

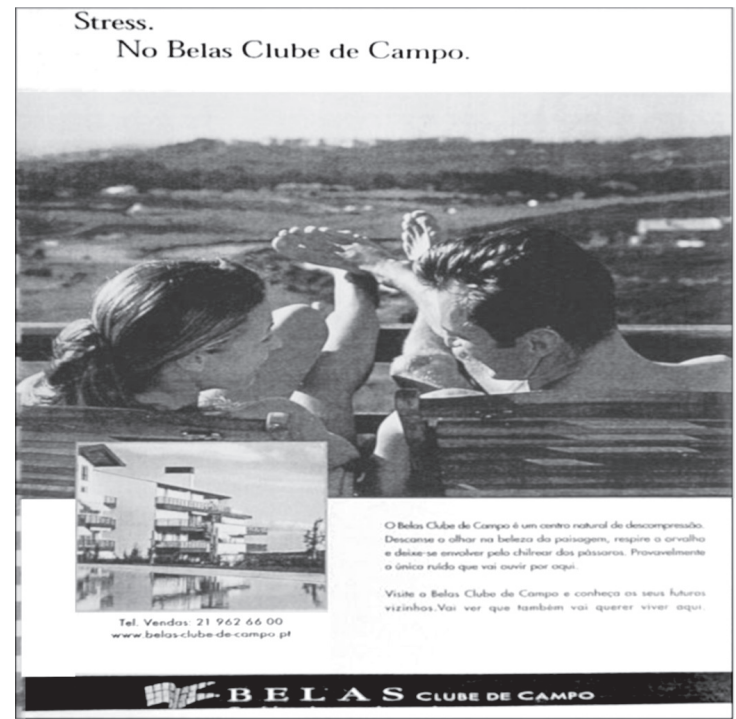

Segundo ressalta dos discursos, a qualidade dos CHF reportam não tanto às características da casa, mas às características do conjunto articulado entre edifício e sua imediata vizinhança próxima: seja pela existência de equipamentos/espaços de posse e usufruto comum (particularmente importantes, o ter espaços verdes), seja pelo cuidado votado à preservação/ manutenção desses espaços. Importante será reter que, na apreciação das qualidades dos CHF e na avaliação da actual situação habitacional, a casa (fogo) é, para os residentes entrevistados, um tema ausente ou secundarizado (inclusivamente na descrição do processo de mudança para a actual situação residencial dos inquiridos) ${ }^{8}$.

7. Além da fuga à falta de qualidade urbana, o desejo de promoção social é, segundo os entrevistados, a principal razão para se residir, em Lisboa, num CHF. Aí reside quem, assim o desejando, dispõe de condições materiais objectivas que permitem sustentar uma decisão acessível, em Portugal, a franjas minoritárias.
A suposta homogeneidade social desse universo fragiliza-se, contudo, por referências que, insinuadoramente ou peremptoriamente asseveradas, aconselham a diferenciação entre fontes/recursos de prestígio social (dinheiro versus cultura). Os percursos de vida são também importantes para julgar em que moldes se processa o acesso a tais recursos (novos ricos versus ricos). A classificação dos residentes expõe-se então em toda a sua complexidade, nela ressoando os ecos de um jogo de mútuas estratégias de distinção social (Bourdieu, 1979: 117-118).

Imagem 14 - Anúncio ao Estoril Domus, CHF no Estoril, área nobre, situada entre Lisboa e Cascais.

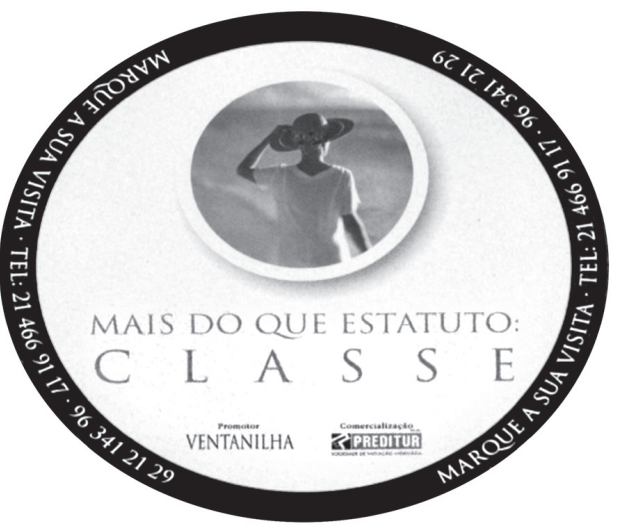

O CHF afigura-se como veículo que permite a aparência da homogeneidade de estatutos: quer para os indivíduos que experimentam fortunas de primeira geração ("novos ricos", "gente com dinheiro mas sem cultura"); quer para aqueles em que a divisão de custos no acesso a equipamentos e espaços colectivos (apanágio dos $\mathrm{CHF}$ ) permite a pessoas que anteriormente tenham experimentado condições económico-sociais anteriormente mais favorecidas, preservar práticas e um estatuto socialmente prestigiantes.

Optar por um CHF pode, assim, sinalizar trajectórias de mobilidade social de sentidos opostos. Na interessante expressão de uma arquitecta-investigadora, o CHF configura "uma situação híbrida": a propriedade/usufruto colectivo de áreas comuns, a divisão de custos implícitas a esta colectivização

\footnotetext{
8 Um resultado que importa relativizar porquanto, também da experiência de pesquisas anteriores, suspeitamos que este silêncio sobre a casa pode relacionar-se com variáveis específicas, como o standing mais ou menos elevado dos empreendimentos. Vale a pena pensar mais aturadamente sobre esta questão.
} 
do espaço privado, não parece coadunar-se com o que seria próprio, sugere, da "classe 'natural' de uma alta burguesia".

8. Aludindo-se à diversificação do produto imobiliário, a distribuição da heterogeneidade social dos residentes expressa e estrutura a classificação dos empreendimentos: o universo dos CHF é arquitectónica, social e simbolicamente heterogéneo. Há uma escala de apreciação em que o estatuto dos CHF não se reduz ao preço dos fogos - um empreendimento mediático como o Belas Clube de Campo, pode ser desvalorizado por autorizar a passagem, no seu interior, de um autocarro público (Martins et al., 2002).

Do percurso de investigação efectuado, poderá considerar-se que, quanto maior o número de habitantes, quanto mais denso, tipologicamente mais diverso, e mais próximo (fisicamente mais acessível, por meios de transportes públicos) menos exclusivo é tendencialmente considerado um CHF. Não deixa de ser curioso verificar que, sendo a dimensão, a densidade e heterogeneidade social elementos classicamente associados ao tipo ideal de cidade (Wirth em Velho: 1967) os CHF considerados mais prestigiados são os que mais dele parecem afastar-se.

9. Fisicamente não penetráveis e socialmente não acessíveis são vários os sentidos associados pelos entrevistados à ideia de fechamento, apanágio deste empreendimentos (quadro 3).

10. A sensação de controlo sobre a envolvente imediata, relativamente à qual se experimenta uma influência directa e "autónoma" (sobretudo negociada entre indivíduos que, mais do que por desejos de afinidades interpessoais, se obrigam e agrupam segundo interesses comuns), define, segundo os entrevistados, a essência do $\mathrm{CHF}^{9}$. $\mathrm{O}$ ascendente sobre a envolvente (que a cidade comum não deixa estabelecer...), manifesta-se numa série de elementos que os entrevistados consideram usuais: muros, vedações, portaria, meios humanos de vigilância e controlo do acesso ao espaço.

A pesquisa sugere a importância de questionar a instrumentalização da noção de segurança na expressão de receios fundados em múltiplos desconfortos e interesses estratégicos. Aglutinados sob um termo único, perdem visibilidade própria, geralmente, em prol do acentuar do medo do crime.

Quadro 3 - Os distintos sentidos recobertos pela ideia de Fechamento

\begin{tabular}{|c|c|}
\hline CHF - espaços não penetráveis & CHF - espaços não acessíveis \\
\hline $\begin{array}{l}\text { Impermeabilidade do perímetro: zonas fortificadas, mu- } \\
\text { ros, artilharia à porta, barreiras físicas que impedem en- } \\
\text { trada no espaço; } \\
\text { Opacidade ao olhar público: olhando de fora (quando se } \\
\text { passa na rua), não se tem a noção do que está lá dentro; } \\
\text { Unicidade e interiorização da entrada para um espaço } \\
\text { interiori. }\end{array}$ & $\begin{array}{l}\text { Restrição do livre direito de admissão, reservado a resi- } \\
\text { dentes e autorizados (os estranhos tolerados); } \\
\text { Alienação face ao contexto externo: objectos arquitectó- } \\
\text { nicos voltados para dentro, implantados sem preocupação } \\
\text { de articulação, continuidade e diálogo com a envolvente } \\
\text { próxima; } \\
\text { Isolamento social: residentes dos CHF's vivem em função } \\
\text { de um interior, no qual concentram a sua atenção e inves- } \\
\text { timento afectivo, não participando ou não se preocupando } \\
\text { com a envolvente; } \\
\text { Exclusividade: só algumas pessoas têm condições objecti- } \\
\text { vas para viver num CHF (é só para alguns). }\end{array}$ \\
\hline
\end{tabular}

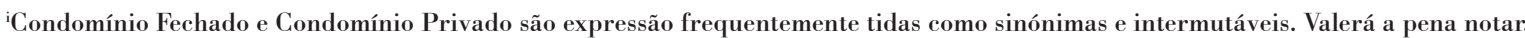
contudo, que em países como o Brasil, por exemplo, estes termos designam configurações morfológicas distintas. Assim, condomínio privado refere-se a empreendimentos em que cada edifício - mesmo que partilhando um espaco interior, comum - dispõe de uma entrada própria e autonomamente acedida pelo público. A expressão condomínio fechado aplica-se a empreendimentos acedidos por uma única entrada comum, nos quais a decisão e o percurso de contacto com os edifícios não são autónomos, sendo interceptado por esse ponto de passagem comum.

\footnotetext{
${ }^{9}$ Na reflexão sobre a origem dos CHF, importa distingui-los de outros modos de apropriação colectiva do espaço para efeitos residenciais. Uma distinção particularmente importante prende-se com a distinção entre CHF e movimentos como o designado co-housing, emergente nas décadas de 60 e 70 do passado século na Dinamarca, apresentado como reacção contra a solidão e os elevados custos das comunidades ditas não-intencionais (Meadows, 1997). Nestes empreendimentos (bofaellesskaber ou comunidades vivas, em Dinamarquês), os futuros residentes procuram conhecer-se antes da própria construção, partilhando decisões sobre o próprio desenho do espaço e, posteriormente, tarefas e espaços concretos no próprio espaço de residência (por exemplo, cozinhas e salas de leitura).
} 
Imagem 15 - Anúncio ao Quinta da Graciosa, no Estoril. Será interessante notar que entre as ameaças expostas no texto que enquadra e ilustra o slogan nenhuma reporta a problemas associados à insegurança provocada pelo crime/vandalismo.

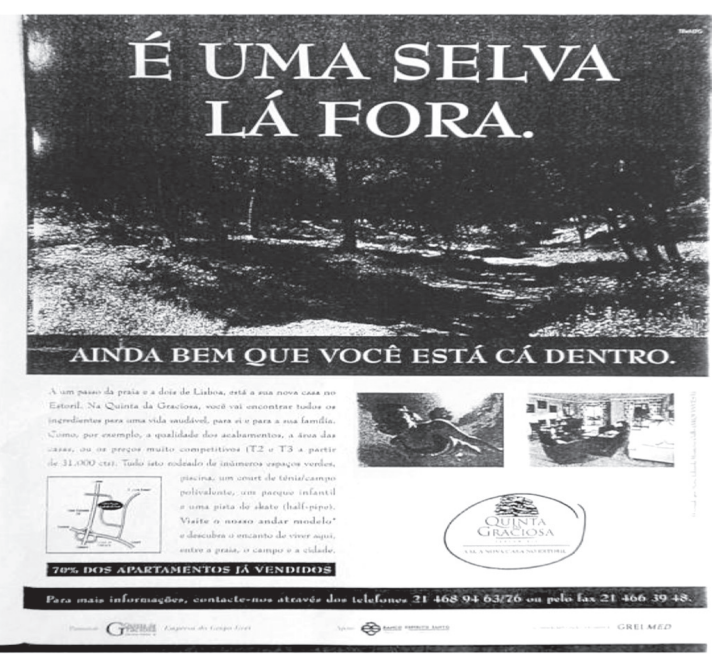

Uma ameaça é algo social e culturalmente mediado (Kasperson, sd: 158-159). Sobretudo entendida como "expressão de uma representação social do meio" (Frias, 2004: 2), a relação entre sentimento de insegurança e expansão de CHF é um processo, fundeado num "modo de comportamento político", ao qual subjaz, segundo Francesco Indovina (2001: 19), "a projecção, no plano colectivo, de incertezas sociais individuais".

No desencontro entre o incremento do nível de vida, e transformação das aspirações, necessidades e exigências reivindicadas à acção do Estado, a construção social do sentimento de insegurança encontra âmbitos diversos de nidificação. Num mundo que parece conhecer-se mais e compreender menos, de desconfiança difusa nas instituições políticas da modernidade e ante a emergência de novos paradigmas ecológicos (Catton e Dunlap, Burns e Flam, citados em Silva, 2002: 23-35), optam alguns por sublinhar a vertente ontológica de tal insegurança (Giddens, 1998).

Segundo ressalta da análise dos discursos, os sentidos recobertos pela ideia de segurança e de insegurança reportam, nos discursos analisados, a múltiplos sentidos. Não desprezando a protecção face ao crime - reconhecida como marca tendencialmente presente nos/dos CHF - o trânsito é um factor frequentemente referenciado como elemento ameaçador, indutor de repulsa pela cidade presente: pelo incómodo do ruído e poluição no quotidiano; pelo que sinaliza de ausência de ordem planeada e pela ameaça que representa à integridade física das crianças. Também pela menor exposição ao trânsito e adopção de regras próprias internas, o CHF oferece a oportunidade de brincar ao ar livre, redescobrindo formas de entretenimento mais comuns na cidade de antes. Algo relatado noutros trabalhos, nomeadamente de Setha Low, para quem "os residentes nas gated communities querem recapturar elementos físicos das paisagens que imaginam como sendo da sua infância" assim "recriando e projectando nos filhos, memórias felizes" (2003: 76-77).

Quadro 4 - Segurança: um espaço de atributos de sentidos díspares

\begin{tabular}{|c|c|}
\hline CHF: espaços seguros & CHF: espaços inseguros \\
\hline Abrigo (protecção contra o crime) & Atraem a cobiça dos ladrões \\
\hline Investimento (valorização das habitações) & \\
\hline Gestão preventiva do espaço colectivo & cos de maior degradação do espaço \\
\hline $\begin{array}{l}\text { Amparo (reforço de ideia de grupo de vizinhos que se re- } \\
\text { conhecem e espreitam, mesmo não sendo próximos, mes- }\end{array}$ & $\begin{array}{l}\text { Espaços de transgressão (crianças que brincam sozinhas } \\
\text { no exterior, fumam à noite, às escondidas, no jardim) }\end{array}$ \\
\hline mo não se conhecendo) & Inacessibilidade (perigo em caso de evacuação urgente; \\
\hline Fiabilidade (estar entre vizinhos que se obrigam às mes- & \\
\hline mas res & $\begin{array}{l}\text { Cenários perfeitos de vidas de fachada ou modos de vida } \\
\text { menos transparentes - confronto entre fontes de recursos e }\end{array}$ \\
\hline $\begin{array}{l}\text { Autonomia da paisagem (despreocupação relativa à evo- } \\
\text { lução actual/futura da envolvente próxima, a qual não } \\
\text { afecta directamente o espaço interior do CHF) }\end{array}$ & $\begin{array}{l}\text { percursos de vida dos vizinhos (de onde lhes vem o dinhei- } \\
\text { ro...) }\end{array}$ \\
\hline $\begin{array}{l}\text { Protecção face ao tráfego (defesa da integridade física } \\
\text { das crianças) }\end{array}$ & Reforço de sentimentos e fenómenos de insegurança (pela \\
\hline $\begin{array}{l}\text { Preservação da integridade moral das crianças ("não en- } \\
\text { tram as tentacôes" ex: droga) }\end{array}$ & ço da sofisticação do crime) \\
\hline Salubridade do espaço ao ar livre (limpeza) & $\begin{array}{l}\text { Efeitos perversos na auto-sustentação da indústria da se- } \\
\text { gurança (histórias sobre quadrilhas criminosas associa- } \\
\text { das à preservação dos interesses desse sector) }\end{array}$ \\
\hline
\end{tabular}


O tema da segurança espreita também quando os CHF surgem referenciados como espaços vocacionados para o enraizamento de afectos, territórios percepcionados como efectivamente intervencionados e eficientemente gerido pelos próprios indivíduos, junto de outros que se obrigam às mesmas regras de conduta.

Mas, como exposto no quadro 4, nem sempre os CF são considerados espaços de amenização de riscos e controlo preventivo da insegurança...

11. A generalidade dos entrevistados considera que optar por um CHF beneficia a situação residencial particular das crianças, reformados $\mathrm{e}$ donas-de-casa - grupos tipos com maior disponibilidade de tempo para aproveitar as amenidades, e maior necessidade de acompanhamento.

Para os residentes entrevistados, a actual situação residencial não potencia a vontade de mudar, em Lisboa, para outra casa. $\mathrm{O}$ quadro 5 resume os principais impactes que, segundo emerge da análise dos conteúdos recolhidos, os condomínios fechados projectam ao nível individual (sobre os que neles residem); colectivo (sobre tais residentes, enquanto colectivo de vizinhos) e sobre a cidade.

Quadro 5 - Impactes dos CHF

\begin{tabular}{|c|c|c|}
\hline & Positivos & Negativos \\
\hline Individuais & $\begin{array}{l}\text { Poupança, funcionalidade no acesso a espaços ver- } \\
\text { des, desporto e lazer (abandonar sedentarismo de } \\
\text { sofá) } \\
\text { Facilidade de estacionamento } \\
\text { Silêncio } \\
\text { Ter um jardim } \\
\text { Mais provável delegação de funções de administra- } \\
\text { ção } \\
\text { Envolvente próxima cuidada } \\
\text { Ter vistas lindas (ver jardins, espaços cuidados) } \\
\text { Autonomia da paisagem (despreocupação em rela- } \\
\text { ção à evolução da envolvente) } \\
\text { Brincar ao ar livre (contacto com natureza, desen- } \\
\text { volvimento de competências sociais de relaciona- } \\
\text { mento das crianças } \\
\text { Não ficar fechado em casa (sair de casa à noite, fu- } \\
\text { mar no jardim) } \\
\text { Prestígio social }\end{array}$ & $\begin{array}{l}\text { Artificialidade do meio (Dessocialização) } \\
\text { Custos manutenção onerosos } \\
\text { Preconceito em relação a quem vive num CHF (fre- } \\
\text { quentemente tidos como snobs) } \\
\text { Potencial dispersão do núcleo familiar }\end{array}$ \\
\hline Colectivos & $\begin{array}{l}\text { Reforço de posição negocial face a prestadores de } \\
\text { serviços } \\
\text { Envolvimento/responsabilização na gestão colectiva } \\
\text { do espaço } \\
\text { Impor regras na envolvente próxima } \\
\text { Eventual espessamento das relações de vizinhança } \\
\text { (sobretudo entre as crianças) } \\
\text { Liberdade extra para os pais (crianças brincam na } \\
\text { rua e circulam entre as casas de vizinhos conheci- } \\
\text { dos) } \\
\text { Prevenção (e não resolução) de problemas }\end{array}$ & $\begin{array}{l}\text { Previsão e resolução antecipada de problemas/con- } \\
\text { flitos } \rightarrow \text { Excessiva regulação das relações } \\
\text { Excessiva personalização das relações } \\
\text { Perda de privacidade (quebra do anonimato) } \\
\text { Mais equipamentos } \rightarrow \text { mais riscos de manutenção }\end{array}$ \\
\hline
\end{tabular}




\section{Interrogações futuras}

O surgimento e expansão dos CHF convida-nos a interpelar, de forma indissociável, Espaço, Cidade e Democracia, revestindo-se tal interpelação de um particular potencial estratégico na discussão em torno da cidade que (pensamos que) temos e sua transformação na cidade que queremos.

A análise das representações associadas ao fenómeno despoleta a exposição dum elenco de reivindicações em relação à cidade, tornando visível um conjunto de julgamentos, em alguns aspectos, indicia-se, partilhados de forma socialmente mais extensa, não sendo específicas daqueles que autonomamente escolhem residir nestes empreendimentos.

No diálogo estabelecido entre actores diversamente associados à produção social de CHF, emerge, por entre linhas de ruptura, um interessante e preocupante espaço de consenso, nele se aclarando um conjunto de preocupações sobre $a$ cidade actualmente existente, partilhadas entre confessados adeptos e assumidos opositores destes empreendimentos. Ao elenco de reivindicações captadas subjaz a exigência de novos padrões de Qualidade de Vida, noção multidimensional, relativa e evolutiva, historicamente tecida, no século $\mathrm{xx}$, entre o incremento do nível e conforto de vida, e o aumento das expectativas em relação à acção dos poderes públicos, num caldo cultural marcado pela emergência de valores pós-materialistas.

Neste contexto, importa pensar que a percepção da qualidade da habitação não "se confina ao alojamento (enquanto objecto de referência)" estendendo-se, sim, "aos espaços em que os indivíduos se posicionam, se movem, e se fazem representar num complexo campo relacional de expressão colectiva" (Freitas, 2001: 270). À própria noção de Qualidade é intrínseca, pois, a ideia de possibilidade de escolha:

" (...) a qualidade significa o poder e a capacidade para escolher (...) significa a capacidade para gerir as diferenças na proximidade, a possibilidade de comutar entre privado e público, o que é local e global, o que é individual e o que é comunal, o que foi ontem e o que poderá ser amanhã, o que permanece e o que se transforma;" significando ainda, subsequentemente, "a democratização destes poderes (...) e capacidades" (Idem, ibidem: 444).
Na curiosa definição de uma entrevistada, ${ }^{6} \boldsymbol{a}$ qualidade de vida é a vida que eu procuro."

Ante novas reivindicações e expectativas relativamente às características da cidade e seu governo $^{10}$, quando as representações associadas aos motivos para a procura de CHF em Lisboa distinguem não apenas uma componente reactiva (ante um estado da cidade presente), mas também uma componente pró-activa - associada à efectiva possibilidade de escolha e ao cumprimento, através dessa escolha, de desejos e de estratégias residenciais - como poderá a Cidade responder?

Endereçado o desafio, quando colocada em evidência a importância da vizinhança próxima na expressão das qualidades que, segundo os entrevistados, distinguem os CHF da generalidade dos condomínios convencionais, que modelos de parceria, que responsabilidades e que espaços de negociação importa estabelecer entre Estado e Privados, perante urgentes tarefas de reabilitação, revitalização, reconversão, regeneração... da cidade?

E se a Cidade é também uma rede de vizinhanças próximas - quando a patrimonialização de alguns espaços da cidade se expõe em toda a sua complexidade e conflitualidade - que dinâmicas de ocupação do espaço se escolhe privilegiar? A este propósito, pululam, em Lisboa, potenciais objectos de estudo...

Conforme emerge da análise dos discursos, a caracterização da cidade presente, é pontuada por concepções sobre a cidade de antes que a retratam como espaço idealizado, obscurecendo-se os dados históricos menos felizes, que contraditam essa imagem sobre o passado.

Ainda assim, note-se que os mesmos factores associados pelos entrevistados a uma lamentável desagregação das vizinhanças e penosa desumanização da cidade e empobrecimento da cidadania, são, simultaneamente, manifestações de desenvolvimento. O aumento do nível de vida, o acesso generalizado aos meios de transporte e às formas de comunicação à distância, por exemplo, são conquistas de que não se dispõem a abdicar.

Deste ponto de vista, não raras vezes, o espessamento de relações de vizinhança próxima a que estilizadamente se alude sinaliza, na prática, contextos territoriais que usualmente classificamos como socialmente excluídos. Importando também

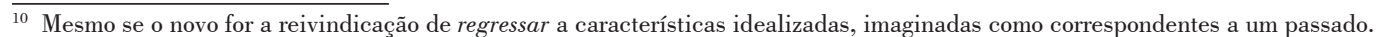


reconhecer que a suposta desumanização da cidade é algo que a investigação tende a relativizar, detectada a existência de práticas e representações que confrontam o clássico comunidade-sociedade (Gemeinschaft - Gesellschaft) como uma efectiva construção ideal-típica.

Também no decurso da pesquisa, assiste-se à denúncia dos residentes em CHF como indivíduos em défice dos sentidos de cidadania e responsabilidade social. Importa investir na operacionalização orientada para a exploração desta hipótese, recorrentemente tida como essencialmente subjacente à decisão de residir num CHF. Em que aspectos outros se concretiza tal distanciamento? Como observar tal atitude e práticas, sendo que a averiguação da acuidade da suposição convida ao estabelecimento de grupos de controlo, representativos da população que não reside (porque não quer, porque não pode) em CHF?

Numa resposta maioritária e recorrente noutros trabalhos, salienta-se que na cidade ideal, não existiriam CHF. Esta é uma resposta importante. Sublinham alguns, que tal existência alcança sentido em meios (social) ecologicamente imperfeitos e marcados pela desigualdade. Onde a população se assume genericamente equiparada rareiam tais empreendimentos. Tal equiparação não está apenas associada à equidade das condições objectivas de vida, prendendo-se também com o acesso e com a partilha de factores associados à qualidade do espaço urbano de acesso público. Ou seja, a qualidade do contexto residencial é estratégica no potenciar ou não a premência da distinção social.

Os CHF são objectos que aclaram de forma particularmente paradigmática o desafio da conjugação entre público, privado e continuidade urbana. Evidenciada a importância das características da vizinhança próxima na formulação da satisfação residencial e da percepção da qualidade de vida, redescobre-se também a importância de pensar o verbo projectar, em Arquitectura. Sobretudo, tendo presente que, como refere Wolfgang Zucker, a "erecção de um limite que separe o interior do exterior é o acto arquitectónico primevo" (Coelho, 2000: 33) ...
Do ponto de vista teórico, o indiscutível interesse e forte base científica sustentando a ideia de private urban governance (McKenzie, 2006) tem vindo a sedimentá-la como mote de referência na reflexão produzida no seio da rede internacional de investigação dedicada ao desenvolvimento do fenómeno dos CHF: Private Urban Governance \& Gated Communities. Consideramo-la, contudo, como uma ideia particularmente enigmática, nomeadamente se aceitarmos a tripla ancoragem da noção de Governança, associada a uma dinâmica estabelecida entre instâncias públicas de governo, sector privado e sociedade civil. À luz desta tripla ancoragem, como entender a ideia de private urban governance? É a parte do processo que cabe ao sector privado, particularmente espectacular nos casos de incorporação, previstos nos EUA? Julgamos que vale a pena pensar sobre isto.

Finalmente, reflectindo a dualidade patente nos posicionamentos críticos sobre os impactes do fenómeno do surgimento e expansão dos CHF, fica a interrogação sobre a cidade ideal e do que, nessa cidade, aconteceria: ... todos viveríamos em CHF? ... Não existiriam CHF? ... Todos poderíamos decidir viver ou não em CHF? ... Não seria necessário existir CHF?

Provocação à imaginação sociológica, assumimos o reducionismo da questão. Aceitamos a advertência de um dos entrevistados: a discussão sobre o surgimento e expansão dos CHF não deve esquecer que nada é intrinsecamente mau. E, geralmente, nem bom, acrescentamos... Ainda assim, considerando as concepções dos CHF como um mal/ /bem enquanto posicionamentos ideal-típicos, as possibilidades de resposta enunciadas abrem caminho à investigação de possíveis perfis de posicionamento perante o fenómeno.

$\mathrm{E}$, para alimentar o debate, talvez valha a pena convidar-nos a pensar sobre a possibilidade de resposta que cada um de nós, se a tal instado, seleccionaria... 


\section{Bibliografia}

BOURDIEU, Pierre (1979), La Distinction.Critique Sociale du Jugement, Paris, Minuit.

BLAKELY, Edward, SNYDER, Mary Gail (1997), Fortress America: Gated Communities in the United States, Washington, Brooking Institution Press.

CALDEIRA, Teresa Pires do Rio (2000), Cidade de muros. Crime, segregação e cidadania em São Paulo, São Paulo, Ed. 34/Edusp.

CASTRO, Alexandra (2002), "Espaços públicos, coexistência social e civilidade. Contributos para uma reflexão sobre os espaços públicos urbanos", Cidades. Comunidades e Territórios, n. ${ }^{\circ}$ 5, Lisboa, CET/ISCTE.

COELHO, António Baptista (1998), "Apropriação e satisfação residencial", Sociedade e Território, Lisboa, n. ${ }^{0}$ 25/26, 1998.

COELHO, António Baptista, PEDRO, João Branco (1998), Do Bairro e da Vizinhança à Habitação. Tipologias e caracterização dos níveis físicos residenciais, Lisboa, Laboratório Nacional de Engenharia Civil (Informação Técnica de Arquitectura. ITA 2).

DURO, Inês, MARTINS, Marta, PATRÍCIO, Sandra, PEREIRA, Tiago (2001), Vilas e Condomínios Fechados em 'bairros tradicionais' de Lisboa, Lisboa, ISCTE (componente curricular da licenciatura: Métodos e Técnicas de Investigação Sociológica I)

FERREIRA, Maria Júlia (coord.) (2001), Condomínios Habitacionais Fechados: utopias e realidades, Lisboa, Centro de Estudos de Geografia e Planeamento Regional (série de estudos n. $\left.{ }^{\circ} 4\right)$.

FERREIRA, Vítor Matias (2004), Fascínio da cidade. Memória e projecto da urbanidade, Lisboa, CET/ISCTE / Ler Devagar.

FOLDVARY, Fred (2006), "The economic case for private residential government" in GLASZE, Georg, WEBSTER, Chris, FRANTZ, Klaus (ed.), Private Cities. Global and local perspectives, Routledge, pp. 31-63.

FREITAS, Maria João (2001), Habitação e Cidadania. No trilho da complexidade de processos relacionais generativos, Lisboa, Instituto Superior de Ciências do Trabalho e da Empresa (ISCTE) (dissertação de doutoramento).

FRIAS, Graça (2004), "A construção social do sentimento de insegurança em Portugal na actualidade", em VIII Congresso Luso-Afro-Brasileiro de Ciências Sociais (consultado em: www. ces.uc.pt/lab2004/programa/sessao2)

GIDDENS, Anthony (1998), As Consequências da Modernidade, Oeiras, Celta Editora.

GUERRA, Isabel (1987), A territorialização das relações sociais: elementos para a análise da vida social local, Lisboa, ISCTE.

GUERRA, Isabel (1994), "As pessoas não são coisas que se metam em gavetas", Sociedade e Território, n. ${ }^{\circ}$ 20, Porto, Ed. Afrontamento.

GOMES, Catarina, Censos 2001 arranca hoje, in Público, 28 de Fevereiro de 2001.

INDOVINA, Francesco (2001) "Geologia da Insegurança Urbana", Cidades-Comunidades e Territórios, n. ${ }^{\circ}$ 2, Lisboa, CET/ISCTE.
INGLEHART, Ronald (1997), Modernization and potmodernization: cultural, econmic, and political change in 43 societies, Princeton, University Press.

KASPERSON, Roger (1992), "The social amplification of Risk: progress in developing an integrative framework" in KRIMSKY, Sheldon, GOLDING, Dominic, (eds.), Social Theories of Risk, London, Praeger.

LEACH, Edmund (1978), Cultura e Comunicação. A lógica pela qual os símbolos estão ligados, Rio de Janeiro, Zahar Editores.

LIMA, Antónia (1997), "Trabalho de campo com famílias da elite empresarial de Lisboa: um terreno para a análise e o exercício de relações de poder", Ethnologia, n. ${ }^{\text {os }}$ 6-8 (Nova série), Lisboa, Edições Cosmos (FCSH-UNL).

LOW, Setha (2003), Behind the gates. Life, security, and the pursuit of happiness in Fortress America, New York, Routledge.

MARTINS, Marta (2006), Condomínio Fechado: Viagem ao espaço... de uma ideia, Lisboa, ISCTE (dissertação de licenciatura).

MARTINS, Marta, PATRÍCIO, Sandra, PEREIRA, Tiago, SANTOS, Joana (2002), Olhares por detrás do muro: Condomínios Habitacionais Fechados na Area Metropolitana de Lisboa, Lisboa, ISCTE (componente curricular da licenciatura: Sociologia da Cidade e Território).

McKENZIE E. (2006), "The Dynamics of Privatopia: Private Residential Governance in the USA", GLASZE, G., WEBSTER, C., FRANTZ, K. (eds.), Private Cities: Global and Local Perspectives, New York, Routledge.

MEADOWS, Donella (1997), "Co-housing: Somewhere between Neighborhood and Commune", in MEADOWS, Donella, The Global Citizen (Consultado em: www.pcdf.org/meadows).

MENEZES, Marluci, Mouraria (2004), Retalhos de Um Imaginário. Significados urbanos de um bairro de Lisboa, Oeiras, Celta Editora.

PINTO, Teresa Costa (2004), “Qualidade de Vida. Reflexões e debates em torno de um conceito", Cidades, Comunidades e Territórios, Lisboa, n. ${ }^{\circ}$ 9, CET-ISCTE.

RAPOSO, Maria Rita Duarte (2002), Novas Paisagens: a produção social de condomínios fechados na Área Metropolitana de Lisboa, Lisboa, ISEG-UTL (dissertação de doutoramento).

RAPOSO, Rita, COTTA, Diogo, MARTINS, Marta et al. (2007), Relatório "Confiança e Condomínios Fechados", in Projecto Sociedade de Confiança: a Construção Social da Confiança em Portugal, Lisboa, SOCIUS - Centro de Investigação em Sociologia Económica e das Organizações, Instituto Superior de Economia e Gestão - Universidade Técnica de Lisboa (ISEG-UTL).

SILVA, Delta (2002), À espera da cheia? Paradoxos da modificação do ambiente por via da tecnologia, Lisboa, ISCTE (dissertação de mestrado).

WIRTH, Louis (1987), "O urbanismo como modo de vida" in VELHO, Gilberto (org.), O fenómeno urbano, Rio de Janeiro, Ed. Guanabara.

www.olhares.com 